\title{
A Stipendium Hungaricum program szerepe a magyar agrár-felsőoktatás nemzetköziesítésében
}

\author{
The Role of the Stipendium Hungaricum Program \\ in the Internationalisation of \\ Hungarian Agricultural Higher Education
}

Janik Menrietta és Naárné Tóth Zsuzsanna

https://doi.org/10.47707/Kulugvi Szemle.2021.4.8

Összefoglaló: A jelen tanulmányhoz fưződő kutatásban először a „ke leti nyitás", majd 2016-tól a "déli nyitás” gazdaságpolitikájához kapcsolt Stipendium Hungaricum (SH) programnak a magyar agrár-felsőoktatás nemzetköziesítésében betöltött szerepét vizsgáltuk. Megállapítottuk, hogy a teljes idős képzésre érkező külföldi hallgatók számának a 2013-tól kezdődően megmutatkozó, jelentős mértékű növekedésében az SH meghatározó szerepet játszik. A legnagyobb kérdés azonban az, hogy egy sikeres program hosszú távon hogyan tudja tartósan növelni a küllföldi önköltséges hallgatói létszámot, amely elősegíti az intézmények önfenntartó képességét. A programra a keleti és a déli nyitás gazdaságpolitikája által megcélzott országok hallgatói jogosultak pályázni, ami közvetetten a gazdasági kapcsolatok erősítését és a minőségfejlesztést is szolgálja. A kormányközi kétoldalú együttmúködések vizsgálata egyrészt a nemzetközivé válásnak a felsőoktatásban tapasztalható dinamikájára fókuszál, másrészt a kormány által támogatott ösztöndíjak gyakorlati szerepét tárja fel. A 2015-2019-es időszakra vonatkozóan képzési területenként vizsgáltuk a külföldi és azon belül az SH-hallgatói létszámot, annak emelkedő trendjét, majd a képzési szintenként jelentkezỏ létszámmegoszlás vizsgálata során kizárólag az agrárterületre és a két legnagyobb befogadó intézményre fókuszáltunk. Az SH program ösztönző hatása az agrárszektorban különösen két hazai intézmény, a Debreceni Egyetem és a Szent István Egye tem esetében bír kimondott jelentőséggel. A tanulmány fő célja az agrárkép zési területen az SH program keretein belüli potenciálok kiaknázási lehetősé geinek a feltárása, ezáltal az agrárium versenyképességének a növelése. 


\section{Külïgyi Szemle}

Kulcsszavak: nemzetköziesítés, diplomácia, Slipendium Hungaricum program, külföldi hallgatók, Debreceni Egyetem, Szent István Egyetem

Abstract: In the present research, the role of Stipendium Hungaricum (SH) program is examined, linked to the economic policy of first "Opening to the East" then from 2016 "Opening to South" in the internationalisation of Hungarian agricultural higher education. It has been found that the program plays a key role in the significant growth of the number of foreign students coming to fulltime education from 2013 onvards. The most challenging question, however, is how a successful program can substantially increase the number of self-funded international students in the long run to foster the self-sustaining capacity of institutions. Students from the countries targeted by the economic policy of 'Opening to the East and South" are eligible to apply for the program, and it also indirectly serves to strengthen economic relations and improve quality. On the one hand, the examination of the intergovernmental bilateral cooperation focuses on the dynamics of internationalisation in higher education; on the other hand, the practical role of government-funded scholarships is explored. First, the number of foreign students, including SH scholars, and their increasing numbers between 2015-2019 have been examined. Secondly, the agricultural field and the two largest host institutions have received primary focus. The incentive effect of SH program in the agricultural sector is of particular importance in case of two Hungarian institutions, namely, the University of Debrecen and Szent Istvan University. This study aims to explore the impacts of exploiting the potential in the field of agricultural training within the framework of SH program. thus providing space for improving the competitiveness of agriculture.

Keywords: internationalisation of higher education, diplomacy, Stipendium Hungaricum scholarship, international students, University of Debrecen, Szent István University

\section{Bevezetés}

A felsőoktatás nemzetköziesítése világszerte dinamikusan zajló folyamat, amelynek a megragadása éppen ezért nem könnyű feladat. E folyamatot gyakran a hallgatói mobilitásra és az idegen nyelven nyújtott képzésekre egyszerúsítik le, pedig - ahogy a szakértők mondják - a felsőoktatás nemzetköziesedése ennél többet kellene hogy jelentsen. 
Több mint egy évtizede Bologna volt az a politikai téma, amely köré az európai felsőoktatási rendszerek nagyobb fokú koherenciájának a fokozására, valamint e rendszerek reformjára és korszerúsítésére irányuló erőfeszítéseket szervezték. Bologna kreatív és dinamikus folyamatnak bizonyult, többféle közvetett és közvetlen hatással. A sikere jelentősen meghaladta az eredeti nyilatkozatot aláirók szándékait és törekvéseit. Bolognának azonban most szembe kell néznie a változásokkal - mind a gazdasági és politikaiakkal, mind a társadalmi, kulturális és tudományosakkal (Kátai és Naárné, 2020).

A felsőoktatás nemzetköziesedése mögött Európában jelenleg két erőteljes motor áll. Az egyik az Európai Unió társadalompolitikai programja, amely az európai közösség építéséhez kapcsolódik; a másik tisztán piaci: a cégeknek igényüik van egy globális toborzói bázisra az oktatásban. A megnövekedett globalizáció az országok gazdasági egymásrautaltságához vezet, és a fizikai távolság elveszíti jelentősé gét (Vasa és Angeloska, 2020). Az éles versenyben való eredményes részvétel tudatos stratégiát és megfelelő eróforrásokat, illetve azok hatékony felhasználását igényli. A társadalompolitikai közösségépítő célt szolgálja például az uniós finanszírozású Erasmus+ program, míg Magyarországon a keleti és déli nyitás jegyében 2013-ban indított $S t i$ pendium Hungaricum (SH) program az, amely támogatja a felsőoktatás nemzetköziesítését - részben a gazdaságpolitikai célok szolgálatában, részben pedig minőségfejlesztést generálva.

Ebből a szempontból elsősorban a gazdasági követelményekre kell összpontosítani, ki kell aknázni a nemzetközivé válás által létrejövő egyedülálló lehetőségeket, melyek gazdagítják a hallgatók és a személyzet oktatási és kutatási tapasztalatait, valamint katalizálják a felsőok tatás hozzájárulását a globális társadalomhoz. Fontos továbbá, hogy az új típusú kihívások kezeléséhez és azoknak a nemzetköziesítési stratégiákra gyakorolt következményeihez is szükség van a kutatási megközelítések átdolgozására. A felsőoktatás nemzetközivé válásának rendszerszintű változásához a holisztikusabb, interdiszciplináris és transzverzális megközelítés révén át kell gondolni a tudás, a kutatás és az oktatás konceptualizálásának a módját (Robson és Wihlborg, 2019). 


\section{Külïgyi Szemle}

A Magyarország Kormánya által kezdeményezett, 2013-ban útjá ra indított SH program fó célja a 2016-ban megjelent „Fokozatváltás a felsőoktatásban" elnevezésű középtávú szakpolitikai stratégia célkitúzéseinek a megvalósítása. A stratégia kiemeli, hogy az agrárium versenyképességének a növelése és fejlesztése több szempontból is elkerülhetetlen. A magyar lakosság biztonságos és minőségi élelmiszer-ellátása, a szektornak a vidéki gazdaságban és foglalkoztatásban betöltött szerepe egyaránt az agrárium teljesitőképességének a javítását indokolja, közvetve a minőségi agrárszakember-pótlás biz tosításával. A világ élelmiszer-ellátásáért verseny folyik, és azok az országok lesznek a nyertesek, amelyekben a természeti erőforrások - különösen a mezőgazdasági termőterület és a víz - lehetősége, a gazdálkodók és a vállalkozások együttmúködése és tudása lehetőséget teremt a versenyképes és életképes élelmiszertermelésre.

Jelenleg az agrárium által foglalkoztatottak korösszetétele kedve zőtlen, a képzettségi szintjük elmarad az elvárt szinttől. Az agrár vállalkozások versenyképességének biztosítása érdekében elengedhe tetlen a magas színvonalon képzett, naprakész tudással rendelkezó szakemberek jelenléte, a hazánkban tanuló külföldi hallgatóknak a végzést követő itt-tartása, az agrárágazatba való bevonása. Az agrárium árutermelő vállalkozásai körében a végzett agrármérnök szakemberek tekintetében megfogalmazott igények 21. századi elvárásokat tükröznek, s e munkaerőpiaci szükség komoly kihívást jelent az agrár-felsőoktatás számára. A hazai ipar szereplői kifejezetten igénylik a gyakorlatorientált képzésből kikerülő szakembereket, Európa más országaiban (Németország, Hollandia stb.) az ún. kooperatív (vagy a német terminológia szerint itthon használt „duális”) képzés kifejezetten sikeresnek bizonyult. A jelenlegi kétlépcsős képzés a struktúrája miatt nem kínál elegendô lehetőséget a gyakorlati képzésre (különösen igaz ez az egyetemi alapképzésben részt vevỏ hallgatók esetében). A mezőgazdasági/élelmiszeripari vállalkozások és az agrárképzési te rületen szakokat múködtető felsőoktatási intézmények által közösen megvalósított duális képzési modell lassan fejlődik. 
Az SH program elsősorban a keleti és a déli nyitás által érintett relációkra koncentrál, ahonnan nagy érdeklődés mutatkozik a magyar felsőoktatás iránt, de a fejlett országokkal való kapcsolatrendszerben is fontosnak tekintik az ide irányuló mobilitást. Lukács, Völgyi, Filep és Kovács (2020) szerint a magyar felsőoktatási és tudományos intézmények hatékony külföldi képviseletéhez, valamint a magyar felsőoktatási brand építéséhez nélkülözhetetlen az egységes nemzeti kommunikáció.

A jelen tanulmányban képzési területenként tekintjük át a küllföldi hallgatók teljes létszámán belül az SH-hallgatókét, az alapján kitérünk a képzési terüiletenkénti megoszlásukra, majd megvizsgáljuk az SH program népszerűségét az agrárképzési területen belüil, küilön kitérve a legtöbb hallgatót befogadó két egyetemre, valamennyi képzési szintet érintve. Célunk a hallgatói létszám növelési potenciáljainak a feltárása annak érdekében, hogy az intézmények önfenntartó képessége hosszú távon stabilan növekedhessen.

\section{Irodalmi áttekintés}

A nemzetköziesítés a globális oktatás, különösen a felsőoktatás szer ves részévé vált. Évente diákok milliói utaznak át az országhatárokon, hogy külföldön szerezzenek diplomát. Az UNESCO statisztikái szerint 2018-ban több mint 5,5 millió hallgató tanult idegen országban, ami 2,75-szerese a 2000-es 2 milliónak (UNESCO, 2020). Az Amerikai Egyesüllt Államok, az Egyesült Királyság, Franciaország, Németország és Ausztrália hagyományosan a legnagyobb szereplő a nemzetközivé vált felsőoktatás piacán, a nemzetközi hallgatói létszám közel felét fogadják. Ezek a klasszikus úti célok azonban veszítenek a piaci részesedésükből, mivel a régiókon belüli preferencia egyre növekszik a régiók közötti oktatási cserékkel szemben, és számos ázsiai országnak lenyűgöző eredményei vannak abban, hogy vonzó tanulmányi célpontként népszerűsítsék magukat. Ázsia leghíresebb desztinációi közé tartozik Japán, Kína, Dél-Korea, India, mos tanában pedig Szingapúr és Malajzia (Tong, 2020). Míg a felsőoktatás 


\section{Külïgyi Szemle}

nemzetközivé tételével foglalkozó szakirodalomban számos részletes elemzés található ezekről a hagyományosan és feltörekvően népszerủ országokról, a kevésbé népszerű úti célok között nagy a küilönbség. A nemzetközi ösztöndíjprogramokról szóló tipológiai tanulmány szerint 183 ilyen programot szponzorált a felsőoktatásban összesen 196 nemzet nemzeti/szövetségi kormánya. A valóság tehát az, hogy bár egyes országok népszerúbbek, mint mások, tanulmányi célpontokként az országok többségének megvan a maga nemzetköziesítési menetrendje, amely összegezve a nemzetközi hallgatói mobilitás másik felét képezi.

A származási országuk szempontjából a mobilizáló diákokat elve szített tehetségnek tekinthetik (ez az ún. „brain drain” jelenség). Ezek a hallgatók azonban a hazájukban is hozzájárulhatnak a tudásfelvételhez, a technológia korszerűsítéséhez és a kapacitásépítéshez, feltéve, hogy a tanulmányaik után hazatérnek, vagy szoros kapcsolatot tartanak fenn a hazájuk állampolgáraival. A mobil hallgatók olyan tudásra tesznek szert, amelyet gyakran közvetlen személyes interakciók révén osztanak meg, és amelyek lehetôvé tehetik hazájuknak a globális tudáshálózatokba való integrálódását. Egyes kutatások azt sugallják, hogy a tengerentúli hallgatók száma jó előre jelzi a jövőbeni tudósok ellentétes irányú áramlását, és bizonyítékot szolgáltat a szakképzett munkaerő nemzetek közötti jelentős mozgására. Ezenkívüil úgy tűnik, hogy a hallgatói mobilitás mélyebben formálja a nemzetközi tudo mányos együittmúködési hálózatokat, mint akár egy közös nyelv, akár a földrajzi vagy a tudományos közelség (Bhandari, 2019; Kovács és Vasa, 2020).

Németországhoz, Franciaországhoz, Hollandiához vagy Svájchoz viszonyítva Magyarország egy közepes méretű ország Európában, és azoknál sokkal kisebb nemzetközi népszerủséggel rendelkezik a felsőoktatás biztosításában. Ennek ellenére a magyar kormány kiemelten kezeli az SH programot, hogy évente több ezer külföldi hallgató jöjjön ingyen tanulni a magyar felsőoktatási intézményekbe.

2020-ban a világ felsőoktatási intézményei bezártak, hogy megelôzzék a koronavírus-járvány terjedését, ami potenciálisan több mint 
3,9 millió, OECD-országokban tanuló nemzetközi és külföldi hallgatót érintett (UNESCO, 2020). A tagállamoknak nemzeti helyreállítási és rezilienciaépítési terveket kell készíteniük, amelyekben meghatározzák a 2021-2023-ra vonatkozó reform- és beruházási programjukat (Pomázi, 2020).

A lezárások hatással voltak a tanulás folyamatosságára és a tan anyagok átadására, valamint befolyásolta a hallgatóknak a diplomájuk értékérôl és a fogadó országnak a biztonságukra és a jóllétükre vigyázási képességérôl való felfogását.

E változásoknak súlyos következményei lehetnek a nemzetközi hallgatók mobilitása szempontjából az elkövetkezó években (OECD, 2020). A szakirodalmi források egyöntetúen hangsúlyozzák a koronavírus és a digitális oktatási formák terjedése közötti aktuális kap csolatot. A világ számos országában kellett rövid idő alatt személyes oktatásról digitális képzésre váltani, ami segítette az online képzések terjedését (Naciri, Baba, Achbani és Kharbach, 2020; Pragholapati, 2020). Az online képzési formák, online kurzusok, vagyis a MOOC ok elterjedése mellett virtuális kollaborációs platformok is jelen vannak a felsőoktatásban, ahol az online gyakorlat, a kutatás a virtuális és a valóságos tér párhuzamos használatával történik.

Figyelembe véve az SH ösztöndíjprogram e gyakorlati, de akadémiai szempontból figyelmen kíviul hagyott fontosságát, ez a tanulmány - kiemelten kezelve az agrárképzési terüiletet - feltárja az SH ösztöndíjprogram azon alapjait, amelyek fontos szerepet játszanak a annak sikerességében.

1 Massive open online course, azaz tömeges nyílt online kurzus. Olyan webes kur zusokat sorolunk ide, amelyek korlátlan részvételt és online hozzáférést biztosíta nak az interneten keresztül egy egyetemi elóadáshoz - alapesetben ingyenesen. 


\section{Külïgyi Szemle}

\section{A Slipendium Hungaricum program szerepe a felsőoktatás nemzetköziesítésében}

Az oktatás jelentős mértékben hozzájárul a nemzet gazdasági fejlő déséhez, legyen az akár fejlődő, akár fejlett. Az egyik legfontosabb erőforrás e szempontból a humán tőke, vagyis a nemzeti munkaerô. Minőségi oktatás szüikséges a produktív munkaerő biztosításához, ami aztán tartósan elvezet egy nemzet fenntartható gazdasági növekedéséhez és a jóléti társadalomhoz (Zvarikova és Majerova, 2013). Thoppan, Victor, Nathan és Fekete-Farkas (2019) szerint a humán tőkébe való beruházás vezethet el az igazán produktív munkaerő kiala kulásához.

A Stipendium Hungaricum program koordinációjában meghatáro zó szerepe van a Tempus Közalapítványnak. Az 1996-ban létrehozott közalapítvány az Emberi Erőforrások Minisztériuma felügyelete alatt múködő, közhasznú szervezet, amely az általa kezelt programokon keresztül a legnagyobb mértékủ mobilitást szervezi Magyarországon. Feladata, hogy a hazai oktatási és képzési szektort hozzásegítse az európai integráció által kínált lehetőségek hatékony és eredményes kiaknázásához, mindezt itthoni és nemzetközi pályázati programok koordinálásával, képzések kidolgozásával és megvalósításával, vala mint szakértői segítségnyújtással teszi lehetővé.

Az SH program oktatáspolitikai célja, hogy az Európai Unió irányelveivel összhangban elősegítse a magyar felsőoktatás nemzet köziesítését, növelje az intézmények kulturális sokszínűségét, népsze rűsítse a világban a magyar felsőoktatást, és erősítse a magyar tudo mányos elit nemzetközi kapcsolatait. Fontos szempont továbbá, hogy - a potenciális fizetőképes kereslet növelése révén - az önköltséges hallgatók magyarországi tanulmányai az intézmények önfenntartó képességét elősegítsék (Magyarország Kormánya, 2016). A nemzetközi kapcsolatok mindkét fél számára előnyös intézményközi együttmú ködésekben, közös projektekben, sőt akár közös diplomát adó képzé sekben ölthetnek formát. Az SH-ösztöndíj felajánlásának a feltétele, hogy legyen az adott partnerországgal olyan hatályos kormányközi 
keretegyezményünk, amely az oktatás területére is kiterjed. Ennek eredményeként az SH program érdekes esettanulmánynak tűnik, amely nemcsak a nemzetközivé válás dinamikáját mutatja a felsőok tatásban, hanem a kormány által támogatott ösztöndíjak többszörös gyakorlati szerepét is.

A Külgazdasági és Külüigyminisztériumban (KKM) nyolc különbö ző főosztály foglalkozik az ösztöndíjprogrammal, név szerint az Afrika Főosztály, az Ázsia és Óceánia Főosztály, a Kína Főosztály, a Közel-Kelet és Észak-Afrika Főosztály, a Latin-Amerika és Karib-térség Főosztály, a Leggyorsabban Fejlődő Gazdaságok Főosztálya, a Nyugat-Balkán Főosztály, az Oroszország, Kelet-Európa és Közép-Ázsia Főosztály. Az adatokból megállapítható, hogy a partnerek száma az elmúlt öt évben dinamikusan emelkedett. A legtöbb partnerrel és SH ösztöndíjassal a Közel-Kelet és Észak-Afrika Főosztály rendelkezik, pontosan 14 partnerrel és 3326 ösztöndíjassal. A rendelkezésre álló kvótát 2019 óta a Latin-Amerika és Karib-térség, valamint a Leggyor sabban Fejlődő Gazdaságok kivételével valamennyi főosztály kétszáz százalékosan kihasználta. A legfrissebb, 2020/21-es adatok ${ }^{2}$ szerint például az Afrika Főosztály esetében a 430 fős kvótához 930 SHösztöndíjas tartozik.

A program keretén belül Magyarország főszabály szerint teljes - alap-, mester-, osztatlan vagy doktori szintű - képzéseket biztosít, de igény esetén részképzésekre is fogad hallgatókat. Azt, hogy az adott partner hallgatói milyen tudományterületekre jelentkezhetnek, az együttmúködési megállapodások rögzítik. Az egyes tudományterüileteken belül valamennyi államilag finanszírozott magyar felsőoktatási intézmény képzése nyitva áll a jelentkezők számára.

A jelen tanulmányban az elmúlt öt év adatait vizsgáljuk. Ennek oka, hogy az SH-ösztöndíjasokra vonatkozó adatok a Felsőoktatási Információs Rendszer (FIR) Országos Statisztikai Adatfelvételi Program (OSAP) statisztikai moduljában a 2015/16-os tanévtől állnak ren delkezésre.

2 Forrás: Külgazdasági és Külüigyminisztérium, Stipendium Hungaricum Főosztály, 2021 . 


\section{Külïgyi Szemle}

A 2015/2016-os tanév őszi szemeszterében az Oktatási Hivatal ál tal szolgáltatott statisztikai adatok szerint összesen 295.316 hallgató tanult felsőoktatási intézményben, 8,9 százalékuk (26.155fő) itt tanuló külföldi, akik közül 4,9 százalék (1270 fö) részesüilt SH-ösztöndíjban. A 2013 ószén, 47 fővel indult programban a 2019/2020-as tanévben a 38.422 küllföldi hallgatónak már 23,5 százaléka, mintegy 9035 fő vett részt (Oklatási Hivatal, 2021).

Az 1. ábrán látható, hogy miközben a hazai hallgatói létszám 3,4 szá zalékkal csökkent, addig a küllföldieké (teljes létszám, a részképzéses hallgatók beszámításával) 46,9 százalékkal nôtt, az SH-hallgatói létszám pedig kimagaslóan, 711 százalékkal emelkedett a 2015 és 2019 közötti időszakban. A felsőoktatásban tanulók létszámának a csökkenése jelentős negatív hatásokat is kiválthat, emellett az oktatási intézmények mûködését és gazdálkodását is számottevően megne hezíti. Az egyetemek és a főiskolák költségvetési stabilitása azért fontos, mert a hallgatói létszám expanziójának időszakában több felsőoktatási intézmény komoly beruházásokat valósított meg hitelből, illetve az úgynevezett public-private partnership ${ }^{3}$ programok keretében. Összességében tehát kijelenthető, hogy a felsőoktatási rendszer működésének biztonsága szempontjából kulcsfontosságú a megfelelő hallgatói létszám garantálása. Erre pedig van is esély, ugyanis egyes előrejelzések szerint az l. ábrán látható csökkenés legfeljebb időszakos folyamat lehet, a nemzetközi versenynek köszönhetően hosszabb távon biztosan meg fog fordulni, hiszen nem szabad megfeledkezni arról, hogy a felsőoktatásunk mellett a hazai gazdaság és munkaerőpiac is nemzetközi összevetésben mûködik, tehát a globális trendek szükségszerűen itt is lecsapódnak. A jelenlegi helyzetre lehet kivá ló megoldás a küllöldi hallgatóknak egy adott ország felsőoktatásá ba történő felvétele, ami azonban bizonyos kihívások elé állíthatja annak felsőoktatási rendszerét. A teljes idejú képzések megnyitása a külföldiek előtt vagy azt feltételezi, hogy az ide érkező hallgatók be szélnek magyarul, vagy pedig azt, hogy az induló képzések elérhetőek

3 A public-private partnership (PPP) a közfeladatoknak a közszféra és a magántőke együittműködésében történő ellátását jelenti. 
valamilyen világnyelven, jellemzően angolul (Kőmíves, 2020; Vasvári, Mayer és Vasa, 2020).

Nemzetközi összehasonlításban is kimagasló a magyar felsőoktatásban részt vevő külföldi hallgatók aránya az egészségügyi, a gaz daságtudományi és a múszaki képzésben, míg a természet-, a böl csészet - és a társadalomtudományok terén alacsonyabb az arányuk (2. ábra). Az adatokból megállapítható, hogy a gazdaságtudományok terén és az azok határterületein akkreditált képzéseken tanuló SH ösztöndíjas hallgatók száma jellemzően növekedett. A külföldi diákok aránya Magyarországon magasabb, mint az OECD-országok átlagában, de ez elsősorban az alap- és a mesterképzésre jelentkezőknek köszönhető, a doktori képzés terén ugyanis alacsonyabb az arányuk. A ki- és bemenő hallgatói mobilitást illetően kiegyenlített a hazai kép (OECD, 2020).

\section{1. ábra ${ }^{4}$}

A hazánkban tanuló összes hallgató, összes küllföldi, valamint SH-hallgató száma (fö) és aránya, 2015-2019

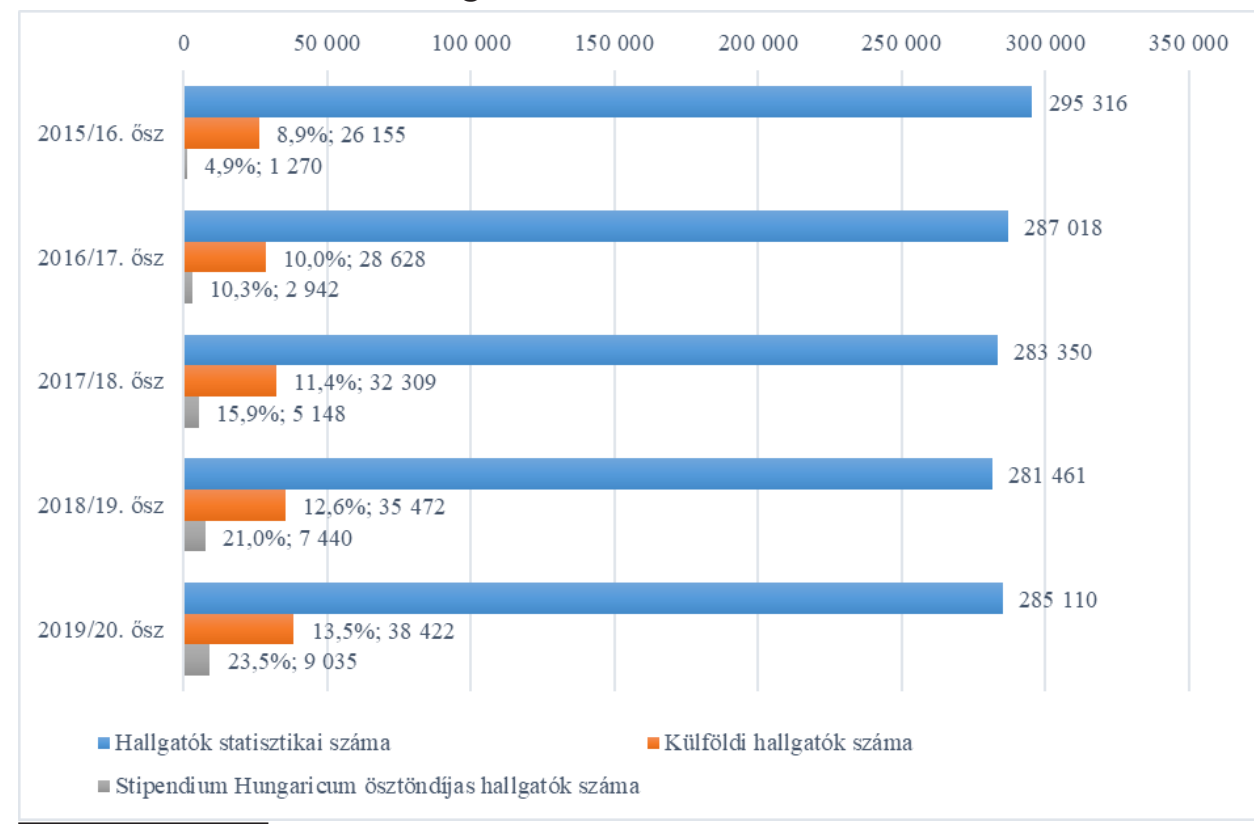

4 Forrás: az Oklatási Hivatal, 2021 alapján saját szerkesztés. 


\section{Külïgyi Szemle}

\section{2. ábra ${ }^{5}$}

A Magyarországon tanuló összes küllföldi hallgató és az SH-hallgatók képzési területenkénti megoszlása (fö), 2019/2020ősz

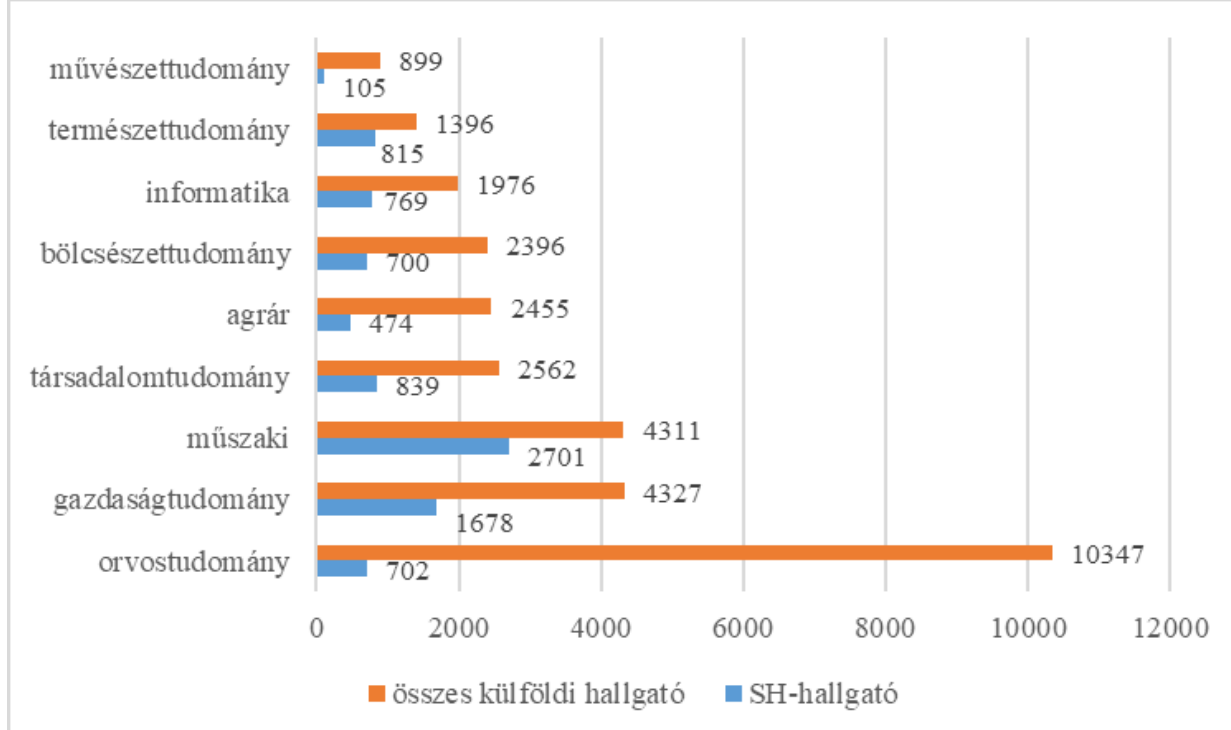

\section{Az agrárteriilet képzési szintenkénti népszerúsége a programon beliil}

Az SH program a külföldi hallgatók erőteljes budapesti koncentrációjának a feloldódásával is jár. Bucsky Péter (2018) adatai szerint az adott felsőoktatási intézménybe járó magyar diákok létszámához képest a legmagasabb arányú küilföldi hallgatói bázissal az Állatorvostudományi Egyetem (51,5\%) és a Semmelweis Egyetem $(28,0 \%)$ rendelkezik, s azokat Pécs (18,6\%), Debrecen (18,5\%) és Szeged (17,1\%) követi. A három városban élók közel 2 százaléka (minden 38-45. lakos) küllföldi diák.

A mesterképzésre jelentkezők száma közel a másfélszeresére emelkedett az elmúlt években. A Magyarországon nappali munkarendben tanuló külföldiek száma mesterképzésen 2018/2019-ben 4952 fó

5 Forrás: az Oktatási Hivatal, 2021 alapján saját szerkesztés. 
volt. A hallgatók nagy arányban érkeztek a szomszédos országok mellett Kínából, Szíriából, Azerbajdzsánból és Jordániából. A legnépszerúbb szakok a nemzetközi tanulmányok, a nemzetközi gazdaság és gazdálkodás, a pszichológia, a vezetés és szervezés, valamint a mérnökinformatikus. Az SH program hatása a mesterképzésen már megfigyelhető: 2019/2020-ban az 1558 küllföldi hallgatóból 1061, tehát a 68 százalékuk SH-ösztöndíjjal tanult Magyarországon; ez az arány 2016-ban még csak 37 százalék volt (Oktatási Hivatal, 2021).

Agrárképzési területen a 474 SH-hallgató (2019/20 ôsz) közül 363 an mesterszakon tanulnak, ezért ez a fő vizsgálandó terüilet. Közüilük 188 fơ a két legnagyobb befogadó egyetemen kap SH-ösztöndịjat.

A Tempus Közalapítvány (2020) felmérése szerint a doktori szin tủ tanulmányokat folytató nemzetközi hallgatók körében az SH ösztöndíjaknak kiemelt vonzerejük van, így az azt igénylők száma di namikusan növekszik (3. ábra). A külföldi doktoranduszok leginkább a gazdálkodás- és szervezéstudományokat is magukban foglaló társadalomtudományi képzések és kutatások területén csatlakoztak be a hazai felsőoktatás világába, így az elnyert ösztöndịjak tekintélyes része is ezeken a képzőhelyeken hasznosul. A jelen tanulmány azonban mégis az agrárképzési területre fókuszál, mert a kutatásokból az is kiderült, hogy e diszciplína terén az értékgörbe felfelé ívelése figyelhető meg. A 3. ábra adataiból jól látszik, hogy a mesterszakos küllföldi hallgatók körében a legnagyobb az SH-ösztöndịjat elnyertek létszáma. Önmagában egy sikeres ösztöndíjprogram nem elegendő ahhoz, hogy egy egyetem nagyobb számban tudjon küilföldi hallgatókat beiskolázni. Ahhoz jól kialakított és folyamatosan ápolt, fenntartott nemzetközi kapcsolati tőke szüikséges. Az elért eredményeket és a lehetőségeket megfelelően népszerűsíteni is kell, amire az egyik mód az egyetemi honlapok és közösségi médiajelenlét javítása. Az internetes kommunikáció számos lehetőséget tartogat az intézmények és a hallgatók számára, akik megismerhetik a célintézmény képzési portfólióját, oktató karát, campusainak felépítését, közösségi életét (Kőmíves, 2020; Makai és Vasa, 2020). 


\section{Külïgyi Szemle}

3. ábra ${ }^{6}$

A hazánkban tanuló küllföldi hallgatók és a két legnagyobb befogadó egyetem SH-hallgatóinak a létszáma az agrárterületen,

képzési szintenként (fő)

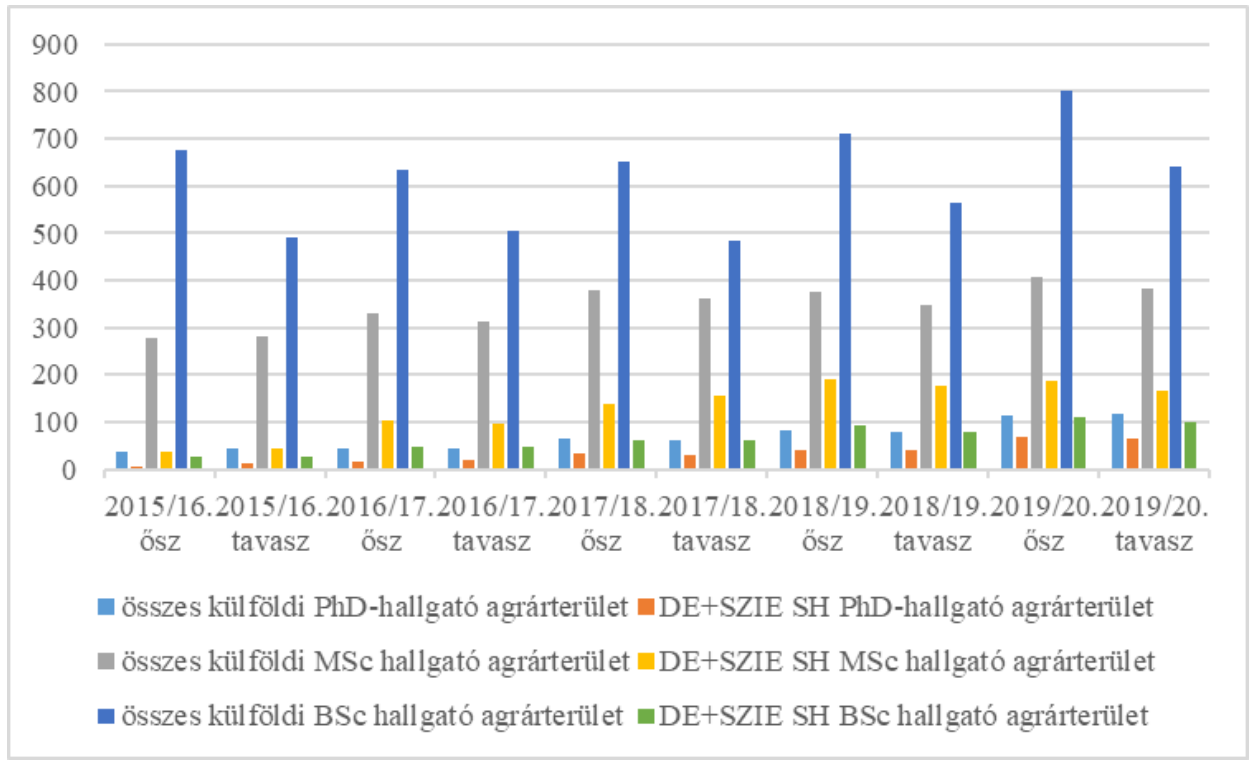

A vizsgált agrárképzési területen az SH-hallgatóknak az országon belüli térbeli eloszlása szerint a Szent István Egyetem és a Debreceni Egyetem szerepel listavezetőként. A 4. ábra adataiból megállapítható, hogy míg 2015/16-ban Gödöllőn 149 küllföldi mesterszakos hallgatóból csupán 20 kapott SH-ösztöndíjat, addig 2019/20-ban már 245 főből 111, tehát igen jelentős hányaduk, 45 százalékuk.

6 Forrás: az Oklatási Hivatal, 2021 alapján saját szerkesztés. 


\section{4. ábra ${ }^{7}$}

A két legnagyobb befogadó egyetem külföldi, illetve SH mesterszakos hallgatóinak a növekedési üteme az agrárképzési terüileten (fö)

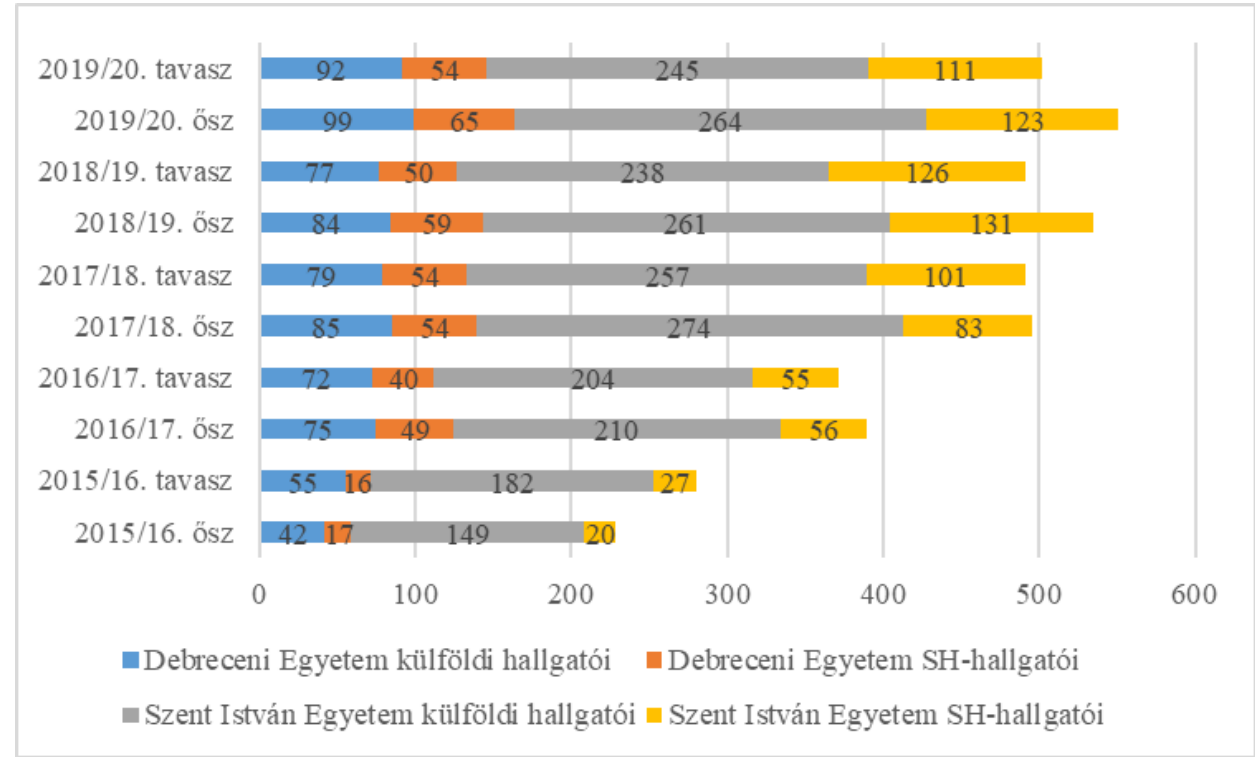

\section{Összefoglalás}

Tanulmányunkban - kiemelten az agrárképzési területet érintően - feltártuk az SH-ösztöndíjprogram azon alapjait, amelyek fontos sze repet játszanak a program sikerességében. A nemzetközi tapasz talatok szerint azok a felsőoktatási rendszerek érnek el sikereket a nemzetközi mobilitási piacon, amelyek mögött koherens kormányzati nemzetköziesítési stratégia és támogató szakpolitika áll. Ennek megfelelően kitüntetett figyelmet kap a felsőoktatás nemzetköziesítése, a mobilitás és az azt támogató ösztöndíjprogramok népszerúsítése.

A jól célzott kormányzati program sikeres implementációja nemcsak az ösztöndíjjal támogatott hallgatókat képes Magyarországra vonzani, hanem azokat a fizetőképes kereslettel rendelkező fiatalokat is, akiket egyébként az egyes hazai egyetemek saját hallgatótoborzó tevékenysége nem tudott volna tanulási céllal hazánkba csábítani.

7 Forrás: az Oklatási Hivatal, 2021 alapján saját szerkesztés. 


\section{Külïgyi Szemle}

Az SH program és az angol nyelvủ képzések elindításának a leg nagyobb hozadéka az, hogy a felsoboktatásban foglalkoztatott kollé gák az idegen nyelvú, elsősorban angolul folytatható kutatásra, ok tatásra és publikációra, összességében az angol nyelvủ tudomány disszeminációra, így a nemzetközi tudományos életben való megjelenésre kapnak lehetőséget, ami a minőségi változás elsődleges alapfeltétele. A programnak köszönhetően a két legnagyobb befoga dó intézmény - a Debreceni Egyetem és a Szent István Egyetem nemzetköziesítési folyamata olyan lendületet kapott, amely során a támogatott szakok és a külföldi hallgatók létszáma dinamikus emelkedésnek indult, ami a magyar agrárium számára gazdasági előnyt jelenthet, valamint a hallgatók által fizetett tandíjak növelik a fogadó város, így az ország bevételeit is. Hosszú távon tehát beigazolódhat, hogy az SH-rendszer képes növelni az önköltséges hallgatók toborzá sát és beiskolázási valószínúségét.

A jelen kutatás azt bizonyítja, hogy a Szent István Egyetem és a Debreceni Egyetem az SH-ösztöndíjat elnyert hallgatók listavezetője az agrárterületen, a tendencia pedig egyre növekvő képet mutat, így az SH-ösztöndíjrendszer néhány éven belül elősegítheti a hazai szakember-utánpótlást. A mesterképzéses és a PhD-hallgatók a kutatómunkájukkal is erősítik a fogadó város gazdaságát, ráadásul a diplomások a végzést követően is a fogadó országban maradhatnak, amely így magasan képzett munkaerőhöz juthat. A hazájukba vissza térő hallgatók pedig a képzőhely országában kialakított kapcsolataik fenntartásával a két térség közötti gazdasági együttmúködést, s közös kutatások előmozditását is segíthetik.

További kutatást igényel, hogy a diploma megszerzését követően a hallgatók hol helyezkednek el, azaz sikerül-e az agrárium teljesítőké pességének a fokozása, a hazánkban tanuló külföldi SH-hallgatóknak a végzést követő „megtartása”.

E tanulmány csak érinti azokat a pandémia okozta hatásokat, amelyek nemcsak a felsőoktatásban, de valamennyi területen inno vatív megoldásokat kínálnak majd a közeljövőben. A felsőoktatási in tézményekben bevezetett online oktatás hatással volt a tanulás fo lyamatosságára és a tananyagok átadására. E változásoknak súlyos 
következményei lehetnek a nemzetközi hallgatók mobilitására is az elkövetkező években. Az online képzési formák és kurzusok elterjedése mellett a virtuális kollaborációs platformok vizsgálata egy következő érdekes vizsgálandó terület lehet.

\section{Irodalomjegyzék}

Bhandari, Rajika (2019). Global Student and Talent Flows: Reexamining the Brain Drain Equation. International Higher Education, 99, 6-7.

Bucsky Péter (2018). Már minden nyolcadik egyetemista küllföldi, nem is múködne nélküilük a magyar felsőoktatás. G7. A letöltés ideje: 2021. május 24. https://g7.hu/kozelet/20180626/mar-minden-nvolcadikegvetemista-kulfoldi-nem-is-mukodne-nelkuluk-a-magvarfelsooktatas.

Kátai Henrietta és Naárné Tóth Zsuzsanna (2020). Mobilitási hajlandóság és területi irányai a Szent István Egyetemen. In Horváth Bálint, Kápolnai Zsombor és Földi Péter (szerk.), Közgazdász Doktoranduszok és Kulalók VI. Nemzelközi Téli Konferenciája. Konferenciakölel (170178. о.).

Kovács Zsolt és Vasa László (2020). A statikus paraméterek és a tényező mátrix dinamikus geopolitikai hatássá konvertálása az innovációs környezet fejlesztésével Szingapúrban. In Dőry Tibor (szerk.), Új paradigmák a vállalatokkal való egyelemi együılmüködésekben (2233. o.).

Kőmíves Péter Miklós (2020). A magyar felsőoklatás nemzelköziesedése a gazdaságludományi képzésekben. Doktori értekezés. Debrecen: Ihrig Károly Gazdálkodás- és Szervezéstudományok Doktori Iskola Debreceni Egyetem Gazdaságtudományi Kar.

Lukács Eszter, Völgyi Katalin, Filep Bálint és Kovács Zsolt (2020). A „Keleti nyitás” politika a magyar felsőoktatás és a Széchenyi István Egyetem nemzetköziesítésében. Külügyi Szemle, 19(1), 80-104.

Magyarország Kormánya (2016). Fokozatváltás a felsőoktatásban. Középtávú szakpolitikai stratégia 2016. A letöltés ideje: 2022. január 6. https://2015-2019.kormany.hu/download/ c/9c/e0000/Fokozatvaltas Felsooktatasban HONLAPRA. PDF\#!DocumentBrowse. 


\section{Külïgyi Szemle}

Makai Attila és Vasa László (2020). A felsőoktatási intézmények szerepe a startup cégek küllhoni inkubációjában. Külïgyi Szemle, 19(1), 105-128.

Naciri, Aziz, Baba, Mohamed Amine, Achbani, Abderrahmane és Kharbach, Ahmed (2020). Mobile Learning in Higher Education: Unavoidable Alternative During COVID-19. Aquademia, 4(1), 1-2.

OECD (2020). Education at a Glance 2020: OECD Indicators. A letöltés ideje: 2022. január 6. https://doi.org/10.1787/19991487.

Oklatási Mivalal (2021). Felsőoktatási statisztikák. A letöltés ideje: 2022. január 6. https:/dari.oktatas.hu/fir stat pub.

Pomázi István (2020). A COVID-19-járvány rendszerszintű következ ményei, tanulságai és lehetséges kiutak. Kïlügyi Szemle, 19, 3-12. A letöltés ideje: 2022. január 6. https://doi.org/10.47707/Kulugvi_ Szemle.2020.4.01.

Pragholapati, Andria (2020). COVID-19 Impact on Students. A letöltés ideje: 2021. május 23. https://edarxiv.org/895ed/.

Robson, Sue és Wihlborg, Monne (2019). Internationalisation of Higher Education: Impacts, Challenges and Future Possibilities. European Educational Research Journal, 18(2), 127-134. A letöltés ideje: 2022. január 6. https://doi.org/10.1177/1474904119834779.

Tempus Közalapívány (2020). A befelé irányuló felsőoktatási mobilitás gazdasági hatásainak mérése. A letöltés ideje: 2022. január 6. https:// tka.hu/kiadvany/14366/a-befele-iranvulo-felsooktatasi-mobilitasgazdasagi-hatasainak-merese.

Thoppan, Jose Joy, Victor, Vijay, Nathan, Robert Jeyakumar és Fekete Farkas Mária (2019). The Worrying Trend of Non-Performing Loans in Higher Education. Forum Scientiae Oeconomia, 7(3). A letöltés ideje: 2022. január 6. https://doi.org/10.23762/FSO_VOL7_NO3_5.

Tong, Linh (2020). Higher Education Internationalization and Dip lomacy: Successes Mixed with Challenges. A Case Study of Hungary's Stipendium Hungaricum Scholarship Program. Hungarian Education Research Journal, 10(4), 382-400. A letöltés ideje: 2022. január 6. https://doi.org/10.1556/063.2020.00036.

UNESCO (2020). Global Flow of Tertiary-Level Students. A letöltés ideje: 2020. október 5. http://uis.unesco.org/en/uis-student-flow.

Vasa László és Angeloska, Aleksandra (2020). Foreign Direct Investment in the Republic of Serbia: Correlation Between Foreign Direct Investments and the Selected Economic Variables. Journal 
of International Studies, 13(1), 170-183. A letöltés ideje: 2022. január. 6. https://www.jois.eu/?585.en_foreign-direct-investmentin-the-republic-of-serbia-correlation-between-foreign-directinvestments-and-the-selected-economic-variables.

Vasvári Bálint, Mayer Gábor és Vasa László (2020). A tudományos és innovációs parkok szerepe a tudásgazdaság és az innovációs ökoszisztéma fejlesztésében. Tér-Gazdaság-Ember, 2(8), 95-109.

Zvaríková, Katarína és Majerová, Jana (2013). Financial Literacy in the Slovak Republic. Procedia - Social and Behavioral Sciences, 110, 1106-1115. A letöltés ideje: 2022. január 6. https://doi.org/10.1016/j. sbspro.2013.12.957. 